\title{
PENERAPAN MODEL PROBLEM BASED LEARNING UNTUK MENINGKATKAN PEMAHAMAN KONSEP MATEMATIKA DITINJAU DARI MULTIPLE INTELLIGENCES SISWA
}

\author{
Kamid $^{1}$, Evita Anggereini ${ }^{2}$, Muhtadin ${ }^{3 *}$ \\ ${ }^{1,2,3}$ Pendidikan Matematika, Universitas Jambi \\ E-mail: muhtadinimmatik@yahoo.co.id ${ }^{3 *)}$
}

Received 26 July 2018; Received in revised form 10 September 2018; Accepted 21 September 2018

\begin{abstract}
This study aimed to determine the activities of teachers and students as well as conceptual understanding of students in terms of multiple intelligences of students by using classroom action research which was conducted in three cycles and each cycle carried out in two meetings. Data collection methods are observation, questionnaire, and tests in each cycle. Based on the results of research activities of teachers and students showed an increase from cycle to cycle. With the results in the first cycle is 57.29\%, the second cycle is $73.44 \%$, and the third cycle is $79.43 \%$ while the activity of students in the first cycle is $56.51 \%$, the second cycle is $71.09 \%$ and the third cycle is $78.13 \%$. Conceptual understanding of students in each intelligence also increased, namely: (1) Interpersonal intelligence and mathematical intelligence in cycle I was $90 \%$, cycle II was $97.92 \%$, and cycle III was $98.21 \%$. (2) Interpersonal intelligence and intra-personal intelligence in cycle I was $56.33 \%$, cycle II was $75.83 \%$, and cycle III was $82.86 \%$. (3) Intra personal intelligence and musical intelligence in cycle I is $70 \%$, cycle II is $83.33 \%$, and cycle III is $87.50 \%$. (4) Interpersonal intelligence and body movement intelligence in cycle I is 50\%, cycle II is $62.5 \%$, and cycle III is $71.43 \%$. (5) Intra personal intelligence and linguistic intelligence in cycle I is $60 \%$, cycle II is $70.83 \%$, and cyce III is 78.57\%. and (6) Naturalist intelligence and intelligence body movements in cycle I were $85 \%$, cycle II was $87.5 \%$, and cycle III was $92.86 \%$
\end{abstract}

Keywords: Multiple Intelligences; Problem Based Learning Model; Understanding Concept.

\section{PENDAHULUAN}

Matematika adalah pelajaran yang memerlukan pemusatan pikiran untuk mengingat dan mengenal semua aturan yang ada dan harus dipenuhi untuk menguasai materi yang dipelajari. Karena, pelajaran matematika terurut, bertingkat dan berkelanjutan. Keberhasilan penguasaan konsep awal akan membuka jalan dalam penyampaian konsep-konsep selanjutnya. Sehingga peserta didik akan lebih mudah dalam memahami konsep matematika pada materi selanjutnya.

Berdasarkan hasil observasi di kelas X Akuntansi SMK Dharma Bhakti 4 Kota Jambi pada tahun 2017. Guru menjelaskan suatu materi, kemudian peserta didik mencatat di buku catatan mereka masing-masing. Pembelajaran seperti ini menunjukkan bahwa guru hanya sebagai penyampai informasi.
Terbukti ketika peserta didik diberi tugas untuk mengerjakan soal, peserta didik mengalami kesulitan dan peserta didik mengakui sulit untuk benar-benar memahami pokok bahasan yang sudah dijelaskan tersebut.

Sebagai contoh lain, ketika peserta didik diminta untuk mengerjakan soal di papan tulis, peserta didik merasa kesulitan dan untuk menyelesaikan soal tersebut, peserta didik membawa buku catatan sebagai pedoman untuk mengerjakan soal di papan tulis dikarenakan peserta didik sudah lupa dengan konsep dari materi yang baru saja telah diajarkan oleh guru.

Peserta didik lebih banyak menghafal konsep matematika yang diberikan guru tanpa mengetahui makna yang diajarkan, sehingga pemahaman peserta didik menjadi lemah. Selain itu sebagai guru masih menggunakan metode yang kurang melibatkan peserta 
didik dalam proses pembelajaran. Menyikapi hal-hal tersebut, bahwa pemahaman konsep matematika penting sehingga guru perlu melaksanakan pembelajaran yang dapat meningkatkan pemahaman konsep matematika peserta didik. Akan tetapi, hal tersebut berkaitan dengan multiple intelligences yang dimiliki peserta didik berbedabeda sudah tentu mempengaruhi cara berfikir peserta didik yang kemudian mempengaruhi pula cara belajar peserta didik dan berpikir logis.

$\begin{array}{ccc}\begin{array}{c}\text { Multiple } \\ \text { berfungsi }\end{array} & \text { maksimal } & \text { dapatigences } \\ \text { untuk }\end{array}$
mengidentifikasi dan mengembangkan kemampuan yang luas dalam diri peserta didik dalam rangka menghasilkan proses belajar yang efektif. Oleh karena itu agar peserta didik mempunyai kemampuan pemahaman konsep yang baik pembelajaran matematika di sekolah hendaknya berpusat kepada peserta didik dengan guru sebagai fasilitator. Guru merupakan salah satu bagian penting yang menghantarkan keberhasilan dalam pendidikan. Sebagaimana yang dijelaskan oleh Rusman (2013) peranan guru meliputi banyak hal, yaitu guru dapat berperan sebagai pengajar, pemimpin kelas, pembimbing, pengatur lingkungan belajar, perencanaan pembelajaran, supervisor, motivator, dan sebagai evaluator. Untuk melaksanakan peran tersebut, guru harus mampu memberikan keteladanan, membangun kemauan, mengembangkan potensi, dan kreativitas peserta didik.

Berdasarkan uraian di atas, guru harus merencanakan proses belajar mengajar yang berorientasi kepada peserta didik. Sebagaimana yang dijelaskan Yamin \& Maisah (2012) Perencanaan merupakan langkahlangkah penting untuk mencapai keberhasilan. Perangkat pembelajaran yang baik dapat memudahkan guru dalam melaksanakan proses belajar mengajar dan melakukan penilaian. Perangkat pembelajaran yang dimaksud berupa Rencana Pelaksanaan Pembelajaran dan Lembar Kerja Peserta didik. Menurut Suyatno (2009) perencanaan proses pembelajaran meliputi silabus dan rencana pelaksanaan pembelajaran (RPP) yang memuat identitas mata pelajaran, standar kompetensi (SK), kompetensi dasar (KD), indikator pencapaian kompetensi tujuan pembelajaran, materi ajar, alokasi waktu, metode pembelajaran, kegiatan pembelajaran, penilaian hasil belajar, dan sumber belajar.

Cara yang dilakukan agar mencapai tujuan dengan menggunakan masalah yang ada di dalam kehidupan peserta didik sebagai awal pembelajaran. Diharapkan dengan menggunakan masalah nyata, pemahaman konsep lebih tertanam di dalam diri peserta didik, sehingga pemahaman yang didapat diaplikasikan secara langsung. Salah satu, pembelajaran yang cocok untuk membantu meningkatkan pemahaman konsep, menggunakan model Problem Based Learning (PBL) atau dikenal juga dengan Model Pembelajaran Berbasis Masalah (PBM), model pembelajaran ini tidak hanya fokus pada penjelasan materi berdasarkan rumus saja dan tentunya dapat membangkitkan semangat peserta didik dalam belajar.

Penerapan model pembelajaran PBL dengan baik akan sangat membantu baik peserta didik maupun guru selama proses belajar. Herlina (2018) mengatakan: karena, pengajaran dengan model PBL memberikan peluang yang lebih besar terhadap siswa untuk mengembangkan kreativitasnya dalam proses belajar, sebab model ini menuntut siswa untuk mampu 
memecahkan dan menyelesaikan masalah pada materi tertentu.

Model pembelajaran pada saat pembelajaran dhadapkan dengan masalah nyata. Dengan demikian, diharapkan peserta didik mampu dalam memecahkan masalah, memiliki pertisipasi dalam kelompok. Menurut Tan dalam Rusman (2013) yang menjelaskan bahwa pembelajaran berbasis masalah merupakan inovasi dalam pembelajaran karena dalam PBM kemampuan berpikir peserta didik betul-betul dioptimalisasikan melalui proses kerja kelompok atau tim yang sistematis, sehingga peserta didik dapat memberdayakan, mengasah, menguji, dan mengembangkan kemampuan berpikirnya secara berkesinambungan.

Atas dasar ini, diharapkan peserta didik memahami konsep serta memiliki keyakinan yang baik terhadap kemampuan penyelesaian masalah. Berdasarkan penjelasan yang dipaparkan dan hasil penelitian yang telah dilakukan maka artikel ini diberi judul "Penerapan Model Problem Based Learning untuk Meningkatkan Pemahaman Konsep Matematika Ditinjau dari Multiple Intelligences Siswa".

Berdasarkan latar belakang masalah pada fokus penelitian di atas, tujuan penelitian ini adalah (1) Untuk mengetahui aktivitas kegiatan guru pada proses pembelajaran matematika dengan model problem based learning. (2) Untuk mengetahui aktivitas kegiatan peserta didik pada proses pembelajaran matematika dengan model problem based learning. (3) Untuk menunjukkan bahwa model problem based learning dapat meningkatkan pemahaman konsep matematika ditinjau dari multiple intelligences peserta didik.

\section{METODE PENELITIAN}

Penelitian ini merupakan jenis penelitian tindakan kelas dengan pendekatan deskriptif kualitatif. Nazir (2005) menjelaskan tujuan dari penelitain deskriptif adalah untuk membuat deskripsi, gambaran atau lukisan secara sistematis, faktual dan akurat mengenai fakta-fakta, sifat-sifat serta serta hubungan antar fenomena yang diselidiki.

Pada penelitian tindakan kelas ini yang menjadi fokus perhatian adalah pemahaman konsep peserta didik ditinjau dari multiple intelligences pada pokok bahasan matriks dan Aktivitas guru dan peserta didik selama proses pembelajaran. Pemahaman konsep dapat diukur dengan menggunakan tes yang dilakukan pada setiap siklus sedangkan Multiple Intelligences peserta didik diukur melalui penyebaran angket kecerdasan, dan aktivitas guru dan siswa diamati menggunakan lembar observasi. Metode pengumpulan data yaitu observasi, tes, dan angket.

Penelitian ini dilaksanakan pada semester genap tahun ajaran 2017/2018 di SMK Dharma Bhakti 4 Kota Jambi pada kelas X Akutansi. Subjek dalam penelitian ini adalah peserta didik kelas X Akutansi SMK Dharma Bhakti 4 Kota Jambi yang berjumlah sebanyak 20 peserta didik. Sedangkan obyek penelitiannya yaitu keseluruhan proses dan hasil pembelajaran menggunakan model problem based learning.

Teknik analisis yang digunakan yaitu mereduksi data, menyajikan data, dan menarik kesimpulan. Tujuannya dianalisis untuk mendapatkan bukti bahwa apakah terjadi pemahaman konsep yang meningkat ditinjau dari multiple intelligences. Analisis data dari sumber-sumber informasi hasil penelitian tersebut adalah sebagai berikut: 
1. Analisis data observasi keterlaksanaan aktivitas guru dan peserta didik analisis secara deskriptif untuk memberikan gambaran pelaksanaan pembelajaran dengan menggunakan model Problem Based Learning.

2. Analisis data kuesioner multiple intelligencces dengan cara mencari dominan kecerdasan dengan memilih 2 kecerdasan yang skornya paling tinggi dimiliki setiap peserta didik. Untuk mengolah data angket dilakukan dengan menggunakan skala likert. Pemberian setiap bobot nilai sesuai pernyataan, yaitu sebagai berikut:

\begin{tabular}{|c|c|} 
Tabel 1. Skor Jawaban Pernyataan \\
\hline Jawaban pernyataan & Skor \\
\hline Sangat Tidak setuju & 1 \\
\hline Tidak Setuju & 2 \\
\hline Agak Stuju & 3 \\
\hline Setuju & 4 \\
\hline Sangat Setuju & 5 \\
\hline
\end{tabular}

3. Analisis data tes dengan deskriptif untuk mengetahui tingkat pemahaman konsep matematika peserta didik ditinjau dari multiple intelligences dikatakan tuntas jika menacapai $\geq 70$ sesuai standar kriteria ketuntasan minimal (KKM) yang telah ditetapkan di SMK dengan menggunakan rumus sebagai berikut:

$$
\mathrm{NP}=\frac{\mathrm{R}}{\mathrm{SM}} \times 100
$$

Keterangan:

NP : Nilai persen yang dicari atau diharapkan

R : Skor mentah yang diperoleh peserta didik

SM : Skor maksimum ideal dari tes yang bersangkutan

100 : Bilangan tetap

Penelitian tindakan kelas ini terdiri dari 3 siklus dan setiap siklus terdiri dari 2 pertemuan yaitu dimluai dari perencanaan, pelaksanaan pendidikan, observasi, dan refleksi. Langkahlangkah penelitian dapat disusun sebagai berikut:

1. Tahap perencanaan ini berupa rancangan pembelajaran. Rencana kegiatan yang dilakukan adalah menyusun rencana pembelajaran dengan model PBL, menyiapkan LKS, menyiapkan perangkat tes serta pedoman penskoran, membuat instrument lembar observasi serta menyiapkan power point.

2. Pelaksanaan yang dilakukan berdasarkan rancangan pembelajaan melalui model Problem Based Learning yang telah direncanakan, yaitu berdasarkan RPP yang telah dipersiapkan.

3. Observasi dilaksanakan selama pelaksanaan tindakan sebagai upaya untuk mengetahui proses pembelajaran.

4. Kegiatan yang dilakukan pada tahap ini adalah mengumpulkan hasil observasi kemudian data yang diperoleh akan dianalisis untuk mengetahui kekurangan atau kelemahan, dan hal-hal yang sudah baik dalam penerapan model pembelajaran serta segala hal yang berkaitan dengan tindakan yang dilaksanakan kemudian direfleksikan yang bertujuan untuk mengevaluasi terhadap proses yang sudah terjadi. Hasil analisis kemudian diperbaiki pada siklus berikutnya.

\section{HASIL PENELITIAN DAN PEMBAHASAN}

Hasil penelitian ini meliputi angket multiple intelligences, hasil observasi Aktivitas kegiatan guru dan peserta didik, dan tes pemahaman konsep. 
Hasil Angket Multiple Intelligences

Hasil tes multiple intelligences ditemukan kecerdasan yang berbedabeda yang dimiliki peserta didik. Analisis data tes multiple intelligences dengan cara mengambil 2 kecerdasan yang skornya paling tinggi. Berdasarkan hasil tes multiple intelligences diperoleh informasi sebagai berikut:

Tabel 2. Kecerdasan yang dmiliki Peserta didik

\begin{tabular}{|c|c|}
\hline Kecerdasan & $\begin{array}{c}\text { Banyak } \\
\text { Responden }\end{array}$ \\
\hline $\begin{array}{ll}\text { 1. Kecerdasan antar pribadi dan } \\
\text { kecerdasan matematis }\end{array}$ & 3 \\
\hline \begin{tabular}{|ll} 
2. & $\begin{array}{l}\text { Kecerdasan antar pribadi dan } \\
\text { kecerdasan intra pribadi }\end{array}$ \\
\end{tabular} & 6 \\
\hline $\begin{array}{l}\text { 3. } \begin{array}{l}\text { Kecerdasan intra pribadi dan } \\
\text { kecerdasan music }\end{array} \\
\end{array}$ & 3 \\
\hline $\begin{array}{l}\text { 4. Kecerdasan antar pribadi dan } \\
\text { kecerdasan gerakan badan }\end{array}$ & 3 \\
\hline $\begin{array}{llll}\text { 5. } & \text { Kecerdasan Intra pribadi dan } \\
\text { kecerdasan linguistic }\end{array}$ & 2 \\
\hline $\begin{array}{l}\text { 6. Kecerdsan naturalis dan kecerdasan } \\
\text { gerakan badan }\end{array}$ & 1 \\
\hline Jumlah & 18 \\
\hline
\end{tabular}

Berdasarkan data kecerdasan yang dimiliki peserta didik maka guru harus melakukan tindakan untuk menciptakan kondisi belajar yang efektif dan peserta didik memahami konsep dengan baik.

\section{Hasil Observasi Kegiatan Guru}

Hasil observasi kegiatan guru pada siklus 1 adalah 57,29\% dengan kriteria cukup baik. Guru akan mengadakan perbaikan yang akan dilakukan pada siklus II. Pada siklus kedua ini hasil penelitian menunjukkan bahwa observasi kegiatan guru berada dalam kategori baik dengan skor 73,44\% yaitu meningkat sebesar $16,15 \%$. Sedangkan pada siklus III menunjukkan hasil yang memuaskan dengan skor adalah 79,43\% mempunyai kriteria baik. Untuk melihat terjadinya peningkatan Aktivitas egiatan guru dari siklus ke siklus dapat dilihat dari gamba I berikut:

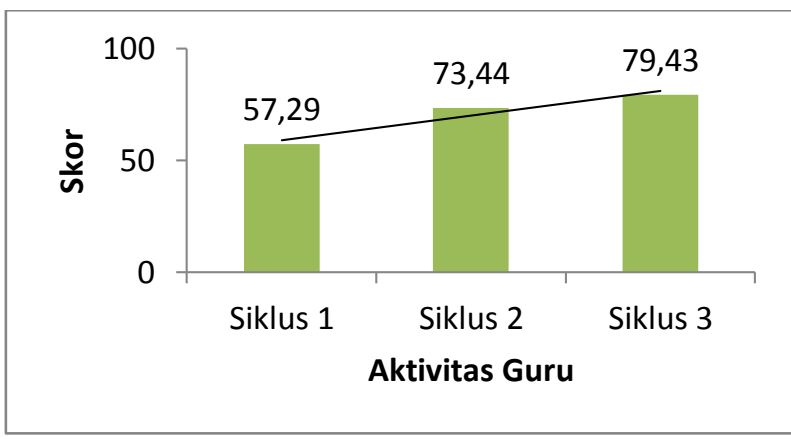

Gambar 1 Perbandingan Observasi Kegiatan Guru

\section{Hasil Observasi Kegiatan Peserta Didik}

Kegiatan peserta didik dalam mengikuti proses pembelajaran dapat diamati selama proses pembelajaran berlangsung. Peserta didik dituntut untuk ikut berpartisipasi aktif dalam proses pembelajaran, sehingga kegiatan peserta didik dapat berjalan dengan baik. Pada siklus I hasil observasi kegiatan peserta didik adalah 56,51\% 
dengan kriteria cukup baik, pada siklus II dalah 71,09\% artinya kegiatan belajar peserta didik mengalami peningkatan sebesar $14,58 \%$ yang berada dalam kategori baik, dan siklus III observasi kegiatan peserta didik berada dalam kategori baik dengan skor 78,13\%. Untuk melihat terjadinya peningkatan observasi kegiatan peserta didik siklus ke siklus dapat dilihat pada gambar dibawah ini:

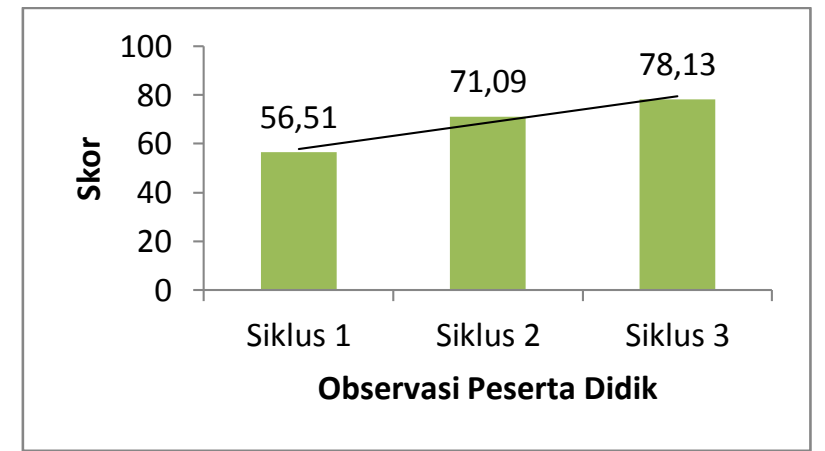

Gambar 2 Perbandingan Observasi Kegiatan Peserta didik

Pada tabel di atas terlihat secara keseluruhan bahwa dari siklus ke siklus mengalami peningkatan persentase keterlaksanaan observasi kegiatan peserta didik. Hal ini disebabkan, guru mampu menguasai penerapan model pembelajaran PBL lebih baik dari sebelumnya.

\section{Pemahaman Konsep Ditinjau dari Multiple Intelligences}

Pemahaman konsep peserta didik ditinjau dari multiple intelligences dari siklus ke siklus mengalami peningkatan. Untuk melihat terjadinya peningkatan pemahaman konsep peserta didik ditinjau dari multiple intelligences dari siklus ke siklus terlihat pada gambar dibawah ini:

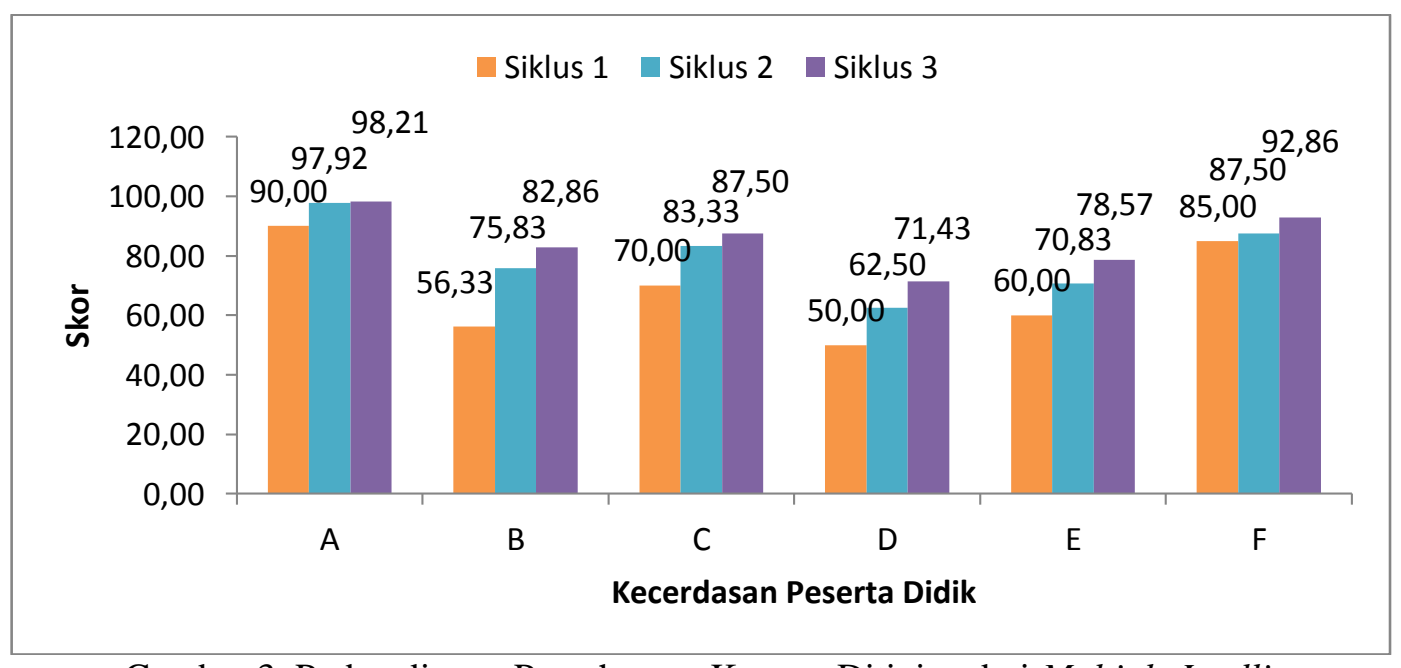

Gambar 3. Perbandingan Pemahaman Konsep Ditinjau dari Multiple Intelligences

Keterangan:
A : Kecerdasan Antar Pribadi dan Kecerdasan Matematis
B : Kecerdasan Antar Pribadi dan Kecerdasan Intra Pribadi
C : Kecerdasan Intra Pribadi dan Kecerdasan Music 
D : Kecerdasan Antar Pribadi dan Kecerdasan Gerakan Badan

E : Kecerdasan Intra Pribadi dan Kecerdasan Linguistik

F : Kecerdsan Naturalis dan Kecerdasan Gerakan Badan

Berdasarkan gambar 3, jelas terlihat adanya peningkatan pada masingmasing kecerdasan selama 3 siklus yang menggunakan model pembelajaran PBL. Hal ini dapat disampaikan bahwa penerapan model pembelajaran PBL dapat meningkatkan pemahaman konsep peserta didik ditinjau dari multiple intelligences khususnya pada materi matriks.

Berdasarkan hasil penelitian bahwa pelaksanaan pembelajaran matematika melalui model problem based learning dapat meningkatkan pemahaman konsep peserta didik. Namun, pemahaman konsep yang dimiliki peserta didik tentunya tidak akan terlepas dari kecerdasan yang dimiliki setiap peserta didik. Hasil penelitian menunjukkan bahwa pemahaman konsep peserta didik terdapat perbedaan antara kecerdasan satu dengan kecerdasan lainnya. Peserta didik yang memiliki kecerdasan matematis jauh lebih unggul dari kecerdasan yang lain. Hasil ini dapat disandarkan dari pendapat Mushollin (2009) bahwa suatu pembelajaran akan menjadi hal yang menyenangkan jika ia sesuai dengan kesenangan dan bakat anak dan anakanak akan berkembang dengan kemampuan dan bakat dasar yang ia senangi dan ia miliki sejak awal. Peserta didik akan lebih mudah memahami pelajaran jika pembelajaran sesuai dengan inteligensi yang dimilikinya.

Setiap peserta didik memiliki kecerdasan yang beragam. Dengan keberagaman ini, peserta didik memiliki tonjolan kecerdasan yang berbeda-beda. Namun, Hamzah (2009) menjelaskan inteligensi bukanlah kemampuan yang tetap tak berubah sepanjang hayat. Inteligensi dapat dikembangkan dan ditingkatkan secara memadai sehingga dapat berfungsi bagi pemiliknya. Dengan demikian, sebagai guru harus berupaya membantu peserta didik dalam proses pembelajaran dengan kecerdasan yang berbeda-beda yang dimiliki peserta didik.

Hasil penelitian menunjukkan bahwa suatu kecerdasan tertentu yang dimiliki peserta didik masing-masing tidak menjadi tolak ukur keberhasilan untuk pemahaman konsep peserta didik. Karena, setiap pemahaman konsep peserta didik pada semua kecerdasan mengalami peningkatan pada tiap siklusnya. Hal ini sesuai yang dijelaskan oleh Purnama dkk (2016) bahwa model pembelajaran berbasis masalah dapat diterapkan pada kelas dengan siswa yang memiliki tingkat inteligensi bervariasi. Dengan melihat kecerdasan yang ada pada peserta didik maka guru perlu membantu perkembangan anak.

Proses pembelajaran matematika agar menjadi optimal, guru harus memperhatikan potensi yang dimiliki peserta didik. Sebagaimana yang dijelaskan oleh Amir (2013) guru perlu menyadari bahwa kecerdasan yang dimiliki oleh masing-masing siswa adalah berbeda-beda. Oleh karena itu, guru harus mampu mengemas setiap materi pembelajaran matematika dengan menarik yang disertai dan sarat dengan pengetahuan yang disesuaikan dengan kondisi local dan potensi yang ada pada siswa atau peserta didik.

Purnama dkk (2016) menjelaskan model pembelajaran berbasis masalah (PBM) juga membantu siswa untuk mengkonstruksikan pengetahuan yang sudah dimiliki dengan pengetahuan baru yang dipelajarinya secara mandiri, sehingga siswa lebih paham akan ilmu yang didapatkan dengan cara menemukan sendiri. 
Berdasarkan observasi pada pelaksanaan pembelajaran dengan menggunakan model problem based learning dan hasil tes telah sesuai dengan ynag diharapkan. Hasil penelitian membuktikan bahwa penerapam model problem based learning dapat meningkatkan pemahaman konsep peserta didik disetiap kecerdasan yang dimiliki siswa.

Penelitian yang dilakukan oleh Arief Trihandoko Saputra (2015) dalam jurnal e-jurnal inovasi pembelajaran SD volume 1 tahun 2015 berjudul "Peningkatan Kemampuan Berpikir Kritis Menggunakan Model Problem Based Learning pada Pembelajaran Tematik Terpadu di Sekolah Dasar" menyimpulkan dalam pembelajaran tematik dengan model problem based learning dapat meningkatkan kemampuan berpikir kritis siswa.

Penelitian yang dilakukan oleh Riana Rahmasari (2016) dalam jurnal Pendidikan Guru Sekolah Dasar edisi 36 tahun ke-35 2016 yang berjudul "Penerapan Model Pembelajaran Problem Based Learning Untuk Meningkatkan Hasil Belajar IPA Kelas IV SD“ dapat diketahui perbandingan nilai pra siklus dan siklus I bahwa dengan model problem based learning dapat meningkatkan hasil belajar IPA peserta didik. Meskipun diterapkan pada tema dan pembelajaran yang berbeda terbukti model problem based learning yang dititik utamakan pada pemberian masalah kepada peserta didik untuk dipecahkan dapat meningkatkan hasil belajar dan berpikir kritis peserta didik.

Penelitian lainnya yang dilakukan oleh Suriana dkk (2016) menyimpulkan terdapat pengaruh terhadap peningkatan pemahaman konsep siswa dengan pembelajaran PBL berbasis eksperimen. Dengan demikian terbukti bahwa model problem based learning dapat meningkatkan pemahaman konsep peserta didik dilihat dari kecerdasan yang dimiliki masing-masing peserta didik.

\section{KESIMPULAN DAN SARAN}

Berdasarkan hasil penelitian dan pembahasan yang telah diuraikan sebelumnya, dapat dismpulkan:

1. Aktivitas kegiatan guru pada siklus I dengan persentase $57,29 \%$, siklus II dengan persentase $73,44 \%$, dan siklus III dengan persentase $79,43 \%$.

2. Aktivitas kegiatan peserta didik pada siklus I dengan persentase $56,51 \%$, siklus II dengan persentase $71,09 \%$ dan siklus III dengan persentase $78,13 \%$.

3. Pemahaman konsep peerta didik ditinjau dari multiple intelligences siswa kelas X SMK DHARMA BHAKTI 4 Kota Jambi. Dengan rincian sebagai berikut:

a. Kecerdasan Antar Pribadi dan Kecerdasan Matematis pada siklus I adalah $90 \%$, siklus II adalah $97,92 \%$, dan pada siklus III adalah 98,21\%.

b. Kecerdasan Antar Pribadi dan Kecerdasan Intra Pribadi pada siklus I adalah 56,33\%, siklus II adalah $75,83 \%$, dan pada siklus III adalah $82,86 \%$.

c. Kecerdasan Intra Pribadi dan Kecerdasan Musik pada siklus I adalah $70 \%$, siklus II adalah $83,33 \%$, dan pada siklus III adalah $87,50 \%$.

d. Kecerdasan Antar Pribadi dan Kecerdasan Gerakan Badan pada siklus I adalah 50\%, siklus II adalah $62,5 \%$, dan pada siklus III adalah $71,43 \%$.

e. Kecerdasan Intra Pribadi dan Kecerdasan Linguistik pada siklus I adalah $60 \%$, siklus II 
adalah $70,83 \%$, dan pada siklus III adalah 78,57\%.

f. Kecerdasan Naturalis dan Kecerdasan Gerakan Badan pada siklus I adalah $85 \%$, siklus II adalah $87,5 \%$, dan pada siklus III adalah $92,86 \%$.

Beberapa saran yang dapat disampaikan berdasarkan hasil penelitian adalah Pembelajaran dengan model PBL guru hendaknya lebih mengoptimalkan perannya sebagai fasilitator, Penggunaan waktu harus tepat sehingga setiap langkah pembelajaran model PBL dapat dilaksanakan maksimal dan penerapan model pembelajaran PBL siswa harus seluruhnya aktif dan kreatif dalam proses belajar. Guru ataupun peneliti harus pandai membawa suasana agar tetap nyaman, karena model PBL ini cenderung dimanfaatkan siswa yang malas hanya ikut serta tanpa partisipasi dalam kelompok.

\section{DAFTAR PUSTAKA}

Amir, Almira. (2013). Pembelajaran Matematika dengan Menggunakan Kecerdasan Majemuk (Multiple Intelligences). Jurnal Logaritma. Vol.1, No. 1, Hal 1-14.

Hamzah, Amir. (2009). Teori Multiple Intelligences dan Implikasinya Terhadap Pengelolaan Pembelajaran. Tadris, Vol 4, No 2, Hal 251-261

Herlina, Febri. (2018). Pengaruh Penerapan Model Problem Based Learning dan Minat Belajar Terhadap Hasil Belajar Ekonomi Siswa Kelas XI IPS SMA Negeri 8 Padang. Jurnal Mahasiswa Pendidikan Ekonomi. Vol 1, No 1, Hal 78-85.

Mushollin. (2009). Penerapan Teori Multiple Intelligences Howard
Gardner dalam Pembelajaran Pendidikan Agama Islam. Tadris. Vol 4, No 2, Hal 223-235.

Nazir. (2005). Metode Penelitian. Bogor: Ghalia Indonesia.

Purnama, Y Ari. Mukhadis Amat \& Nauri I Muda. (2016). Pengaruh Pembelajaran Berbasis Masalah dan Intelegensi Terhadap Hasil Belajar Teknologi Motor Bensin Siswa SMK. Jurnal Teknik Mesin. Vol 24, No 1, Hal 1-13

Rahmasari, R. (2016). Penerapan Model Pembelajaran Problem Based Learning Untuk Meningkatkan Hasil Belajar IPA Kelas IV SD Jurnal Pendidikan Guru Sekolah Dasar, 1-10

Rusman. (2013). Model-model Pembelajaran (Mengembangkan Profesionalisme Guru), Jakarta: Rajawali Pers.

Saputra, A. T. (2015). Peningkatan Kemampuan Berpikir Kritis Menggunakan Model Problem Based Learning pada Pembelajaran Tematik Terpadu di Sekolah Dasar. e-jurnal Inovasi Pembelajaran SD, 1,1-16

Suriana. Halim, Abdul \& Mursal (2016). Penerapan Model Problem Based Learning (PBL) Berbasis Eksperimen Untuk Meningkatkan Pemahaman Konsep Usaha dan Energi Ditinjau dari Gaya Berpikir Siswa da MAN Rukoh Banda Aceh. Jurnal Pendidikan Sainns Indonesia. Vol 4, No 2, Hal 127139.

Suyatno. (2009). Penjelasan Pembelajaran Inovatif. Sidoarjo: Masmedia Buana Pustaka.

Yamin, M \& Maisah. (2012). Manajemen Pembelajaran Kelas. Jakarta: Gaung Persada Press. 